\title{
Effects of host defense peptides B2RP, Brevinin-2GU, D-Lys-Temporin, Lys-XT-7 and D-Lys-Ascaphin-8 on peripheral blood mononuclear cells: Preliminary study
}

\author{
SUZANA POPOVIĆ ${ }^{1}$ \\ PREDRAG DJURDJEVIĆ \\ MILAN ZARIĆ ${ }^{3}$ \\ ŽELJKO MIJAILOVIĆ 4 \\ DUŠKO AVRAMOVIĆ5 \\ DEJAN BASKIĆ ${ }^{1}$ \\ ${ }^{1}$ University of Kragujevac, Serbia, Faculty of \\ Medical Sciences, Department of Microbiology and \\ immunology, Svetozara Markovica 69, Kragujevac, \\ Serbia \\ ${ }^{2}$ University of Kragujevac, Serbia, Faculty of Medical \\ Sciences, Department of Internal medicine, \\ Svetozara Markovica 69, Kragujevac, Serbia, \\ ${ }^{3}$ University of Kragujevac, Serbia, Faculty of Medical \\ Sciences, Department of Biochemistry, Svetozara \\ Markovica 69, Kragujevac, Serbia, \\ ${ }^{4}$ University of Kragujevac, Serbia, Faculty of Medical \\ Sciences, Department of Infectious diseases, \\ Svetozara Markovica 69, Kragujevac, Serbia, \\ ${ }^{5}$ Clinical Center Dr Dragisa Misovic, Heroja Milana \\ Tepica 1, Beograd, Serbia
}

Correspondence:

Suzana Popovic

E-mail: suzana.popovic@medf.kg.ac.rs

Key words: host defence peptides; cytotoxicity; immunomodulation

Received December 06, 2016

Revised March 02, 2017.

Accepted April 12, 2017.

\begin{abstract}
Background and purpose: Host defense peptides have considerable therapeutic potential. One of the limitations for their therapeutic use is insufficient selectivity of some peptides, i.e. toxicity for eukaryotic cells. In this study, we have investigated effect of two naturally occurring and three analogs of frog skin-derived peptides on viability/proliferation of resting peripheral blood mononuclear cells and activated lymphocytes.
\end{abstract}

Materials and Methods: Effect of tested peptides was assessed using MTT colorimetric assay. Concanavalin A was used as lymphocyte mitogen.

Results: Brevinin-2GU induced cell death only in the highest tested concentration, whereas other peptides were not cytotoxic to resting peripheral blood mononuclear cells. Moreover, high concentrations of B2RP, DLys-Ascaphin-8 and Lys-XT-7 induced cell proliferation and this effect was more prominent in lymphocytes $(p<0.05)$. Tested peptides had opposite effect on activated lymphocytes inhibiting proliferative response to Concanavalin A (Brevinin-2GU, B2RP and D-Lys-Temporin $p<0.05$ ).

Conclusions: Tested peptides (with exception of Brevinin-2GU) didn't show cytotoxicity toward peripheral blood mononuclear cells. Moreover, they have potential to modulate immune response by inducing proliferation of resting peripheral blood mononuclear cells and limiting proliferative response to the activation stimulus. Regarding their potent antimicrobial and low hemolytic activity this makes them good candidates for therapeutic use.

\section{INTRODUCTION}

ost defense peptides (HDPs) represent a heterogeneous group of 1 positively charged, amphipathic molecules composed of 12 to 50 amino acids, with diversity of properties. They are found in almost all living organisms, from bacteria to humans (1). HDPs have multiplicity of biological functions. They exert a broad-spectrum antimicrobial activity and therefore are often referred to as "natural antibiotics" (2). The structure and positive net charge of HDPs enable strong binding to negatively charged membranes of microorganisms, as well as cancer cells, that bear more negative net charge than healthy cell (3). Electrostatic binding to outer surface of cell is followed by disruption of membrane structure, binding to vital intracellular molecules and interference with synthesis of macromolecules, resulting in cell death. 
Although the most studied feature of HDPs is their antimicrobial activity, there are opinions that primary task of these peptides is immunomodulation. HDPs promote immune response to inflammation and at the same time restrain it, protecting organism from excessive reaction that can be detrimental for the host (4). They have impact on both innate and adaptive immunity and coordinate their action, influencing various processes, such as proliferation, chemotaxis, cytokine production and activation of adaptive immune response. Furthermore, HDPs participate in wound healing and neovascularization (5).

Currently, potential of HDPs as new therapeutic agents in infectious diseases, cancer and immune-related disorders is objective of increasing number of studies (6). However, although recognized as promising new drugs, there are some limitations for their use. These referre to their sensitivity to enzymatic degradation and inactivation in serum by albumins and low-density lipoproteins, inadequate tissue distribution and potential systemic toxicity owning to their inefficient specificity. To overcome these problems, modifications of peptide structure have been under study (7).

In the present study we have tested effects of five peptides, selected on the basis of their high antimicrobial potency and low hemolytic activity. Naturally occurring peptides Brevinin-2GU (8) and brevinin-2-related peptide-ERa (B2RP-ERa) (9) were isolated from the skin of the Asian frog Hylarana. Analogs [D4k]ascaphin-8, [G4K]XT-7 (10-12) and [T5k]temporin-DRa (13), showing potent antimicrobial and low hemolytic activity, were derived from frog skin peptides that have shown broadspectrum antibacterial activity, but high hemolytic activity.

\section{MATERIALS AND METHODS \\ Peptides}

Brevinin-2GU (GVIIDTLKGAAKT VAAELLRKAHCKLTNSC), B2RP-ERa (GVIKSVLKGVAKTVALGML.NH2), [D4k] ascaphin-8 (GFKkLLKGAAKALVKTVLF.NH2), [G4K]XT-7 (GLLKPLLKIAAKVGSN LL.NH2) and [T5k]temporin-DRa (HFLGkLVNLAKKILNH2), supplied in crude form by GL Biochem Ltd. (Shanghai, China) and purified to near homogeneity by reverse-phase HPLC (>98\%), were a gift from Dr. M. Conlon (United Arab Emirates University, Dubai, UAE).

\section{Cell isolation and culture}

Cells were isolated from peripheral blood of healthy volunteers. Our institutional Ethics Committee approved the study and prior to initiation written informed consent was obtained from all subjects according to the Declaration of Helsinki. Peripheral blood mononuclear cells (PBMNC) were isolated by density gradient centrifugation (Histopaque 1077, Sigma, Germany), washed three times and finally suspended in the supplemented culture medium RPMI 1640 (Sigma, Germany). Lymphocyte population (PBL) was isolated from PBMNC by adherence method (14). Cell number and viability were determined using Acridine orange/Ethidium bromide staining (all from Sigma, Germany).

\section{Cell viability and proliferation assay}

The effect of cationic peptides on peripheral blood mononuclear cells was determined by MTT assay that is widely used for assessing cell proliferation, cell viability, and/or cytotoxicity (15). Mononuclear cells or lymphocytes were grown in 96-well plates at a starting density of $0.2 \times 10^{6}$ cells/well in presence of increasing doses $(1,5,10$ and $20 \mu \mathrm{g} / \mathrm{ml}$ ) of peptides or in medium alone (control). In some experiments Concanavalin A (ConA) was used $(5 \mu \mathrm{g} / \mathrm{ml})$. Cells were cultured for $24 \mathrm{~h}$ at $37^{\circ} \mathrm{C}$ in $5 \% \mathrm{CO}_{2}$. Cultured cells viability was determined by assaying the reduction of MTT to formazan.

\section{Statistics}

The data were expressed as the mean \pm SD. The distributions of data were evaluated for normality using the Kolmogorov-Smirnov test. One-way ANOVA was performed to compare parametric data between more than two groups. When ANOVA indicated significant differences, the Bonferroni test was used to identify intergroup differences. All statistical analyses were carried out with commercial statistical software (SPSS version 13.0; SPSS Inc., Chicago, IL).

\section{RESULTS}

\section{The effect of peptides on cell viability}

As shown in Figure 1., naturally occurring peptide Brevinin-2GU was slightly cytotoxic for PBMNC and PBL, but only the highest concentration $(20 \mu \mathrm{g} / \mathrm{ml})$ decreased PBMNC viability with statistical significance $(\mathrm{p}<0.05)$, whereas effect on PBL was similar, but with no statistical significance. The other naturally occurring peptide, B2RP-ERa, didn't show significant cytotoxicity toward PBMNC. However, it demonstrated opposite effect on PBL, inducing cell proliferation reaching statistical significance with the highest concentrations of 10 and $20 \mu \mathrm{g} / \mathrm{ml}(\mathrm{p}<0.05)$. Similarly, analogs [D4k] ascaphin-8, [G4K] XT-7 and [T5k] temporin-DRa did not show cytotoxic effect to PBMNC and PBL in either concentration tested, while, in contrast, promoted proliferation of both PBMNC and PBL. However, this effect was noticeable only with the highest concentration $(20 \mu \mathrm{g} / \mathrm{ml})$ of [D $4 \mathrm{k}$ ] ascaphin-8, reaching statistical significance for PBL $(\mathrm{p}<0.05)$, and $[\mathrm{G} 4 \mathrm{~K}] \mathrm{XT}-7$, achieving significance for both PBL $(\mathrm{p}<0.001)$ and PBMNC $(\mathrm{p}<0.05)$. Importantly, this mitogenic action of both [D4k] ascaphin-8 and $[\mathrm{G} 4 \mathrm{~K}]$ XT-7 was more prominent in PBL $(\mathrm{p}<0.05)$. 
Brevinin-2GU
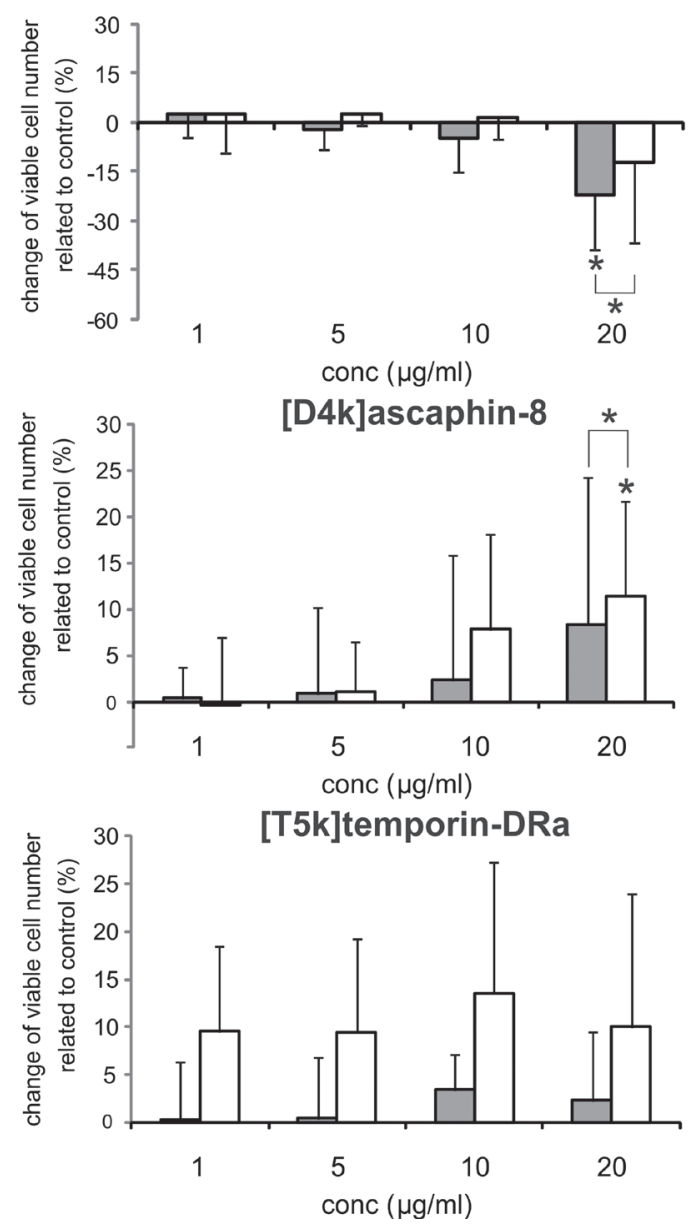

B2RP-ERa
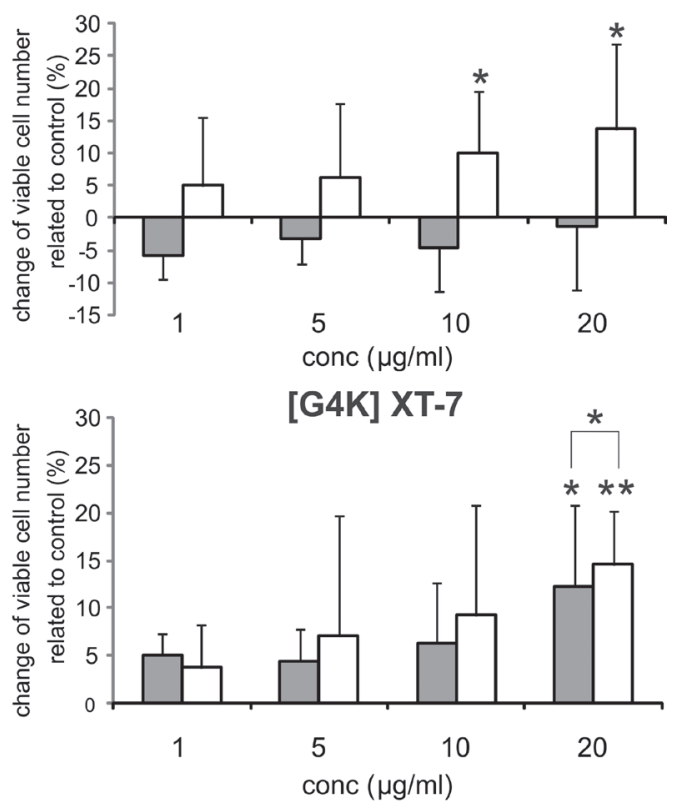

Figure 1. The effect of peptides on PBMNC and PBL.

Peripheral blood mononuclear cells (PBMNC) and purified lymphocytes (PBL) were incubated for $24 \mathrm{~h}$ in media alone (control) and with increasing doses $(1,5,10$ and $20 \mu \mathrm{g} / \mathrm{ml}$ ) of peptides. Cytotoxic or proliferative effect of peptides is presented as percent of change in cell number related to control. The values represent the mean $( \pm \mathrm{SD})$ of five different experiments. ${ }^{*} \mathrm{p}<0.05 ;{ }^{* *} \mathrm{p}<0.001$

\section{Peptides diminished mitogenic effect of ConA}

To determine whether tested peptides have influence on proliferative response induced by Concanavalin A, PBLs were incubated in media alone (control), or treated with $5 \mu \mathrm{g} / \mathrm{ml}$ ConA, either in absence or presence of different concentration of peptides. Our results showed that peptides decrease the mitogenic action of ConA (Figure 2.), and this effect was dose-dependent in that way that increase in concentration of peptides resulted in enhanced inhibition of ConA induced PBL proliferation.

Peripheral blood lymphocytes (PBL) were incubated for $24 \mathrm{~h}$ in media alone (control) and with Concanavalin
A (Con A) $(5 \mu \mathrm{g} / \mathrm{ml})$ either in presence or absence of peptides $(1,5,10$ and $20 \mu \mathrm{g} / \mathrm{ml})$. Proliferative response induced by ConA and influence of tested peptides on the response are presented as percent of change in cell number related to control. The values represent the mean $( \pm S D)$ of five different experiments. ${ }^{*} \mathrm{p}<0.05$

The most potent immunomodulator of all was Brevinin-2GU, that at the highest concentrations (10 and $20 \mu \mathrm{g} / \mathrm{ml}$ ) significantly inhibited ConA-induced proliferation of PBL, and this effect was most pronounced at a concentration of $20 \mu \mathrm{g} / \mathrm{ml}$ which almost completely nullifies the effect of Con $\mathrm{A}(\mathrm{p}<0.05)$. Other peptides showed a similar effect, but statistically significant inhibition of the mitogenic action of Con A, although somewhat less than the Brevinin-2GU, showed only the highest concentrations $(10$ and $20 \mu \mathrm{g} / \mathrm{ml})$ of naturally occurring peptide B2RP-ERa and analog [T5k]temporin-DRa $(\mathrm{p}<0.05)$.

Summarized results are presented in Figure 3.

The effects of host defense peptides on peripheral blood mononuclear cells. 

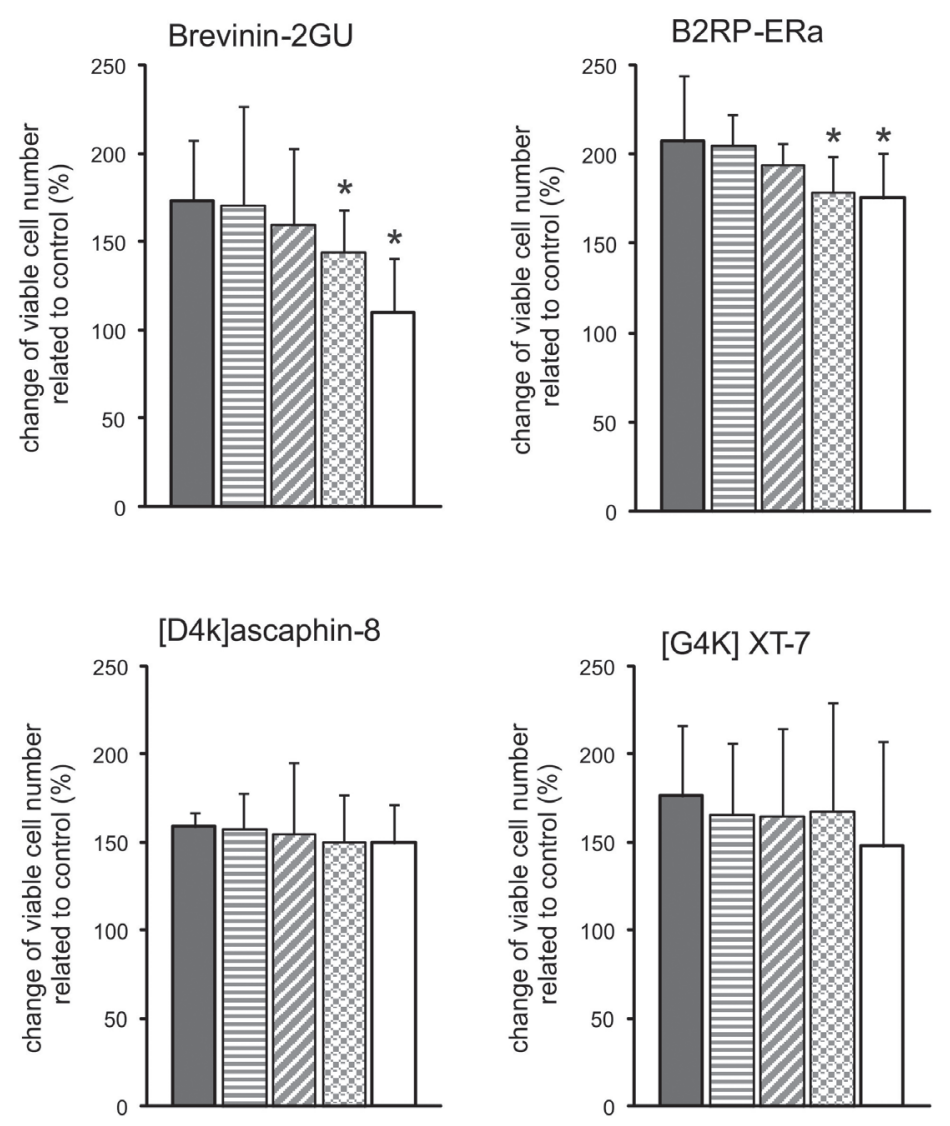

[T5k]temporin-DRa
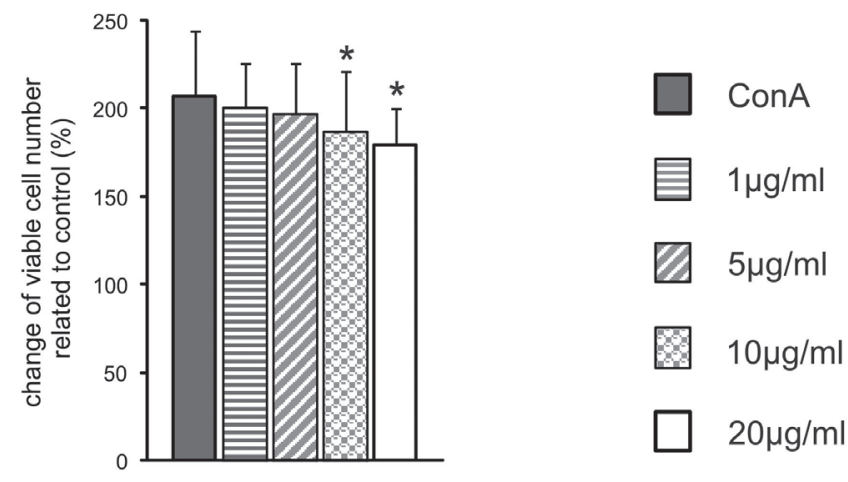

Figure 2. Peptides decreased mitogenic effect of ConA.

\section{DISCUSSION}

In spite of great potential of HDPs as new therapeutics, development of HDP-based drugs is limited by several shortcomings, such as instability and insufficient specificity. Therefore, a number of investigations are directed toward designing analogs of naturally occurring peptides that will outpass these disadvantages. In this study we have investigated effect of two naturally occurring peptides and three analogs on healthy peripheral blood mononuclear cells.

Our results showed that, apart from Brevinin-2GU that was cytotoxic in the highest concentration, tested HDP analogs and naturally occurring peptide B2RP-ERa didn't exhibit cytotoxicity against mononuclear cells isolated from peripheral blood, but rather promoted their proliferation. Our results are consistent with reports certifying that HDPs can enhance proliferation of peripheral blood mononuclear cells (16), which is in accordance with findings about impact of HDPs on immune system response (17). 


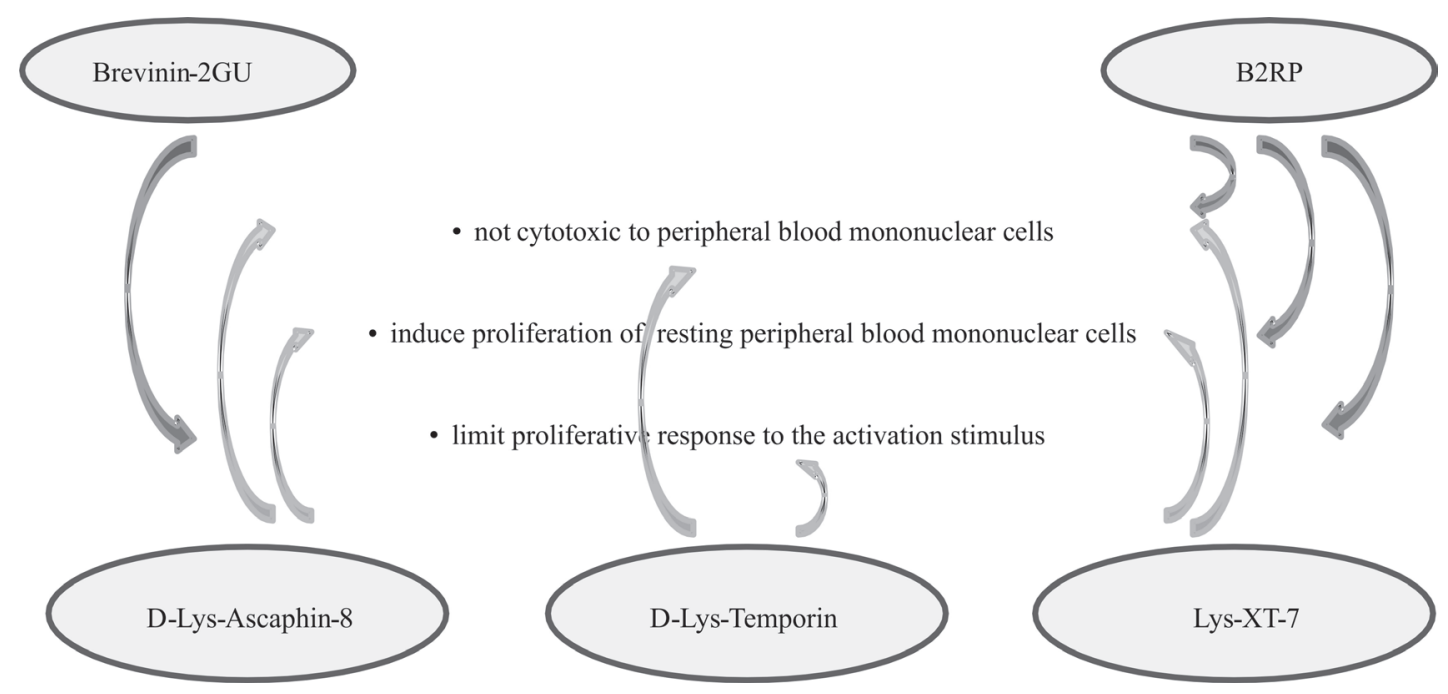

Figure 3. Summarised results of the study.

Activated lymphocytes can be, however, more sensitive to HDPs. The foregoing results have shown that tested peptides had more pronounced effect on macrophage depleted peripheral blood mononuclear cells (PBL). Macrophages are necessary for many lymphocyte functions, including activation and mitogenic response, but can also suppress lymphocyte activation. Furthermore, macrophages can uptake culture medium with peptides via endocytosis and thus reduce their concentration beneath the effective doses required for the effect observed on lymphocytes. Therefore, to exclude influence of macrophages and to test effect of peptides on activated lymphocytes, we incubated PBLs with T-cell mitogen ConA, alone or with different concentration of tested peptides.

All tested peptides decreased proliferative effect of ConA in that way that higher concentration of peptides resulted in higher inhibition. This effect was most prominent with naturally occurring peptides Brevinin-2GU and B2RP-ERa and analog $[\mathrm{T} 5 \mathrm{k}]$ temporin-DRa $(\mathrm{p}<0.05)$. This effect of tested peptides can be a result of their cytotoxicity against activated lymphocytes. Nevertheless, in our previous study we have shown that tested peptides inhibited release of proinflammatory cytokines TNF $\alpha$ and IFN $\gamma$ and stimulated release of antiinflammatory cytokines IL-4, IL-10 and TGF $\beta$ in ConA-stimulated PBLs (18). It is well known that IL-4, IL-10 and TGF $\beta$ can promote cell-cycle arrest and apoptosis $(19,20)$. Therefore it is possible that tested peptides exert their antiproliferative activity through stimulation of antiinflammatory cytokines release. In any case, these results point to their capability to influence immune response.

In conclusion, we have shown that tested peptides (except Brevinin-2GU) are not cytotoxic for resting peripheral blood mononuclear cells and even induce cell proliferation, and that both naturally occurring peptides and analog [T5k]temporin-DRa have potential to modulate immune response to the activation stimulus. Concerning their high antimicrobial potency and low hemolytic activity, these peptides can be considered as potential therapeutics.

Acknowledgments: This study was fully supported by the Faculty of Medical Sciences, University of Kragujevac (JP 08-11).

\section{CONFLICT OF INTEREST}

The authors declare that there are no conflicts of interest.

\section{REFERENCES}

1. BULET P, STOCKLIN R, MENIN L 2004 Antimicrobial peptides: from invertebrates to vertebrates. Immunol Rev 198: 169-84 https://doi.org/10.1111/j.0105-2896.2004.0124.x

2. YEAMAN MR, AND YOUNT NY 2003 Mechanisms of antimicrobial peptide action and resistance. Pharmacol Rev 55: 27-55 https://doi.org/10.1124/pr.55.1.2

3. HOSKIN DW, RAMAMOORTHY A 2008 Studies on anticancer activities of antimicrobial peptides. Biochim Biophys Acta 1778: 357-75 https://doi.org/10.1016/j.bbamem.2007.11.008

4. KANDLER K, SHAYKHIEV R, KLEEMANN P, KLESCZ F, LOHOFF M, VOGELMEIER C, BALS R 2006 The anti-microbial peptide LL-37 inhibits the activation of dendritic cells by TLR ligands. Int Immunol 18: 1729-36 https://doi.org/10.1093/intimm/dxl107

5. CARRETERO M, ESCAMEZ MJ, GARCIA M, DUARTE B, HOLGUIN A, RETAMOSA L, JORCANO JL, RÍO MD, LARCHER F 2008 In vitro and in vivo wound healing-promoting activities of human cathelicidin LL-37. J Invest Dermatol 128: 223-36 https://doi.org/10.1038/sj.jid.5701043

6. YEUNG AT, GELLATLY SL, HANCOCK RE 2011 Multifunctional cationic host defense peptides and their clinical applications. Cell Mol Life Sci 68: 2161-76 https://doi.org/10.1007/s00018-011-0710-x 
7. BROUWER CP, RAHMAN M, WELLING MM 2011 Discovery and development of a synthetic peptide derived from lactoferrin for clinical use. Peptides 32: 1953-63 https://doi.org/10.1016/j.peptides.2011.07.017

8. CONLON JM, GALADARI S, RAZA H, CONDAMINE E 2008 Design of potent, non-toxic antimicrobial agents based upon the naturally occurring frog skin peptides, ascaphin- 8 and peptide XT-7. Chem Biol Drug Des 72: 58-64 https://doi.org/10.1111/j.1747-0285.2008.00671.x

9. AL-GHAFERI N, KOLODZIEJEK J, NOWOTNY N, COQUET L, JOUENNE T, LEPRINCE J, VAUDRY H, KING JD, CONLON JM 2010 Atimicrobial peptides from the skin secretions of the South-East Asian frog Hylarana erythraea (Ranidae). Peptides 31: 548-54 https://doi.org/10.1016/j.peptides.2009.12.013

10. ELEY A, IBRAHIM M, KURDI SE, CONLON JM 2008 Activities of the frog skin peptide, ascaphin- 8 and its lysine-substituted analogs against clinical isolates of extended-spectrum betalactamase (ESBL) producing bacteria. Peptides 29: 25-30 https://doi.org/10.1016/j.peptides.2007.10.026

11. CONLON JM, POWER GJ, ABDEL-WAHAB YH, FLATT PR, JIANSHENG H, COQUET L, LEPRINCE J, JOUENNE T, VAUDRY H 2008 A potent, non-toxic insulin-releasing peptide isolated from an extract of the skin of the Asian frog, Hylarana guntheri (Anura: Ranidae). Regul Pept 151: 153-9 https://doi.org/10.1016/j.regpep.2008.04.002

12. CONLON JM, SONNEVEND A, PÁL T, VILA-FARRÉS X 2012 Efficacy of six frog skin-derived antimicrobial peptides against colistin-resistant strains of the Acinetobacter baumannii group. Int J Antimicrob Agents 39: 317-20 https://doi.org/10.1016/j.ijantimicag.2011.12.005

13. CONLON JM, AL-GHAFERI N, ABRAHAM B, LEPRINCE J 2007 Strategies for transformation of naturally-occurring amphibian antimicrobial peptides into therapeutically valuable antiinfective agents. Methods 42: 349-57

https://doi.org/10.1016/j.ymeth.2007.01.004
14. BASKIC D, ACIMOVIC L, SAMARDZIC G, VUJANOVIC NL, ARSENIJEVIC NN 2001 Blood monocytes and tumor-associated macrophages in human cancer: differences in activation levels. Neoplasma 48: 169-74

15. VERMA A, PRASAD KN, SINGH AK, NYATI KK, GUPTA RK, PALIWAL VK 2010 Evaluation of the MTT lymphocyte proliferation assay for the diagnosis of neurocysticercosis. J Microbiol Methods 81: 175-78 https://doi.org/10.1016/j.mimet.2010.03.001

16. PUJARI R, NAGRE NN, CHACHADI VB, INAMDAR SR, SWAMY BM, SHASTRY P 2010 Rhizoctonia bataticola lectin (RBL) induces mitogenesis and cytokine production in human PBMC via p38 MAPK and STAT-5 signaling pathways. Biochem Biophys Acta 1800: 1268-75 https://doi.org/10.1016/j.bbagen.2010.09.003

17. WUERTH K, HANCOCK RE 2011 New insights into cathelicidin modulation of adaptive immunity. Eur J Immunol 41: 2817-9 https://doi.org/10.1002/eji.201142055

18. POPOVIC S, URBÁN E, LUKIC M, CONLON JM 2012 Peptides with antimicrobial and anti-inflammatory activities that have therapeutic potential for treatment of acne vulgaris. Peptides 34: 275-82 https://doi.org/10.1016/j.peptides.2012.02.010

19. BOUTON LA, RAMIREZ CD, BAILEY DP, YEATMAN CF, YUE J, WRIGHT HV, DOMEN J, ROSATO RR, GRANT S, FISCHER-STENGER K, RYAN JJ 2004 Costimulation with interleukin- 4 and interleukin-10 induces mast cell apoptosis and cell-cycle arrest: the role of $\mathrm{p} 53$ and the mitochondrion. Exp Hematol 32: 1137-45 https://doi.org/10.1016/j.exphem.2004.09.002

20. FRANCIS JM, HEYWORTH CM, SPOONCER E, PIERCE A, DEXTER TM, WHETTON AD 2000 Transforming growth factor-beta 1 induces apoptosis independently of $\mathrm{p} 53$ and selectively reduces expression of $\mathrm{Bcl}-2$ in multipotent hematopoietic cells. J Biol Chem 275: 39137-45 https://doi.org/10.1074/jbc.M007212200 